\title{
Bacterial Analysis of Selected Drinking Water Sources in Mbarara Municipality, Uganda
}

\author{
Ben Lukubye*, Morgan Andama \\ Department of Biology, Mbarara University of Science and Technology, Mbarara, Uganda \\ Email: *lukubyeben@gmail.com
}

How to cite this paper: Lukubye, B. and Andama, M. (2017) Bacterial Analysis of Selected Drinking Water Sources in Mbarara Municipality, Uganda. Journal of Water Resource and Protection, 9, 999-1013. https://doi.org/10.4236/jwarp.2017.98066

Received: June 11, 2017

Accepted: July 8, 2017

Published: July 11, 2017

Copyright $\odot 2017$ by authors and Scientific Research Publishing Inc. This work is licensed under the Creative Commons Attribution International License (CC BY 4.0).

http://creativecommons.org/licenses/by/4.0/ c) (i) Open Access

\begin{abstract}
Surveillance of water quality to ensure microbiological safety is a vital public health function to prevent water borne diseases. Bacterial total coliform and Escherichia coli (E. coli) examination provide indication of the hygienic condition of drinking water and are major tools in the assessment of the health risk borne by pathogen in water. Unfortunately, there is insufficient information on the total coliform and E. coli amounts in the common drinking water sources in Mbarara Municipality, Uganda despite the eminent anthropogenic sources of contamination. Hence the study established the sanitary risk and quantified the total coliform and $E$. coli load in selected drinking water sources in Mbarara Municipality, Uganda. A total of 70 water samples were collected from selected boreholes, springs, wells and rainwater in Nyamitanga, Kamukuzi and Kakoba divisions of Mbarara municipality. The water samples were analysed for total coliform and E. coli abundance using the American Public Health Association (APHA) standard method. The total coliform and Escherichia coli counts were compared with the World Health Organization (WHO) drinking water standard guidelines. The findings indicate that all the studied groundwater sources (boreholes, springs and wells) in Mbarara $\mathrm{Mu}$ nicipality were not compliant to either both or one of the WHO total coliform $(<10 \mathrm{CFU} / 100 \mathrm{ml})$ and E. coli $(0 \mathrm{CFU} / 100 \mathrm{ml})$ criteria for drinking water hence they are unsuitable for drinking without treatment e.g. boiling etc. Only rainwater collected from Mbarara University of Science and Technology met the WHO total coliform and E. coli criteria for drinking water thus is suitable for drinking without any treatment. There is a strong linkage between bacterial (total coliforms and E. coli) water quality and water source sanitation, as well as the proximity of latrines, animal farms and landfills around the water sources. Mbarara municipal council should therefore ensure effective and regular operation and maintenance of the drinking water sources through the adoption and promotion of appropriate water safety plans.
\end{abstract}




\section{Keywords}

Drinking Water Sources, Escherichia coli, Mbarara Municipality, Total Coliforms

\section{Introduction}

Water is an essential element of life on planet Earth and about 75\% of the earth's surface is covered by it [1] [2]. Water is indispensable for human health and well-being as it constitutes $60 \%$ of the human body and is also important for achieving sustainable development [1] [3]. However, of the available water, only $1 \%$ is drinkable [2] and hence much of the world's population lacks access to sufficient and safe water supplies [4]. As a result, most of people especially in the developing countries including Uganda get water from the unsafe water sources. Unfortunately unsafe water is an effective carrier of pathogens (bacteria, viruses, protozoans and some helminthes), capable of transmitting waterborne diseases to a large number of the population with devastating effects [5] [6]. These diseases result from the ingestion of water contaminated with the microbial pathogens from human or animal waste [3].

Waterborne diseases and death continue to be a worldwide burden in both developed and developing countries, the heaviest being diarrhoeal diseases. In Uganda, waterborne diseases have been found to be among the major public health problems [3]. A number of them such as diarrhoeal illness, cholera and typhoid etc. are known to cause health effects [5]. An estimated 30,000 persons die from diarrheal disease every year in Uganda and an annual average of 3000 cases of cholera are reported [7] [8].

The prevalence of waterborne diseases in Uganda is also attributed to poor hygiene and environmental sanitation including inadequate supply of safe water [9]. Only $33 \%$ of the urban population in Uganda had access to adequate sanitation in 2012, a $1 \%$ rise since 1990 while $2 \%$ still practiced open defecation [10]. Furthermore, [8] reported that a population of 13.8 million Ugandans use unsanitary or shared latrines while 3.2 million have no latrine at all and defecate in the open. [11] indicated that pit latrine coverage in Mbarara is at 74 percent. Yet the majority of the rural populations in Uganda get their water supplies from unprotected water, underground water, streams, spring wells, ponds and lakes [12].

In Mbarara district, most rural people get water mainly from borehole (95\%), protected spring (98\%), rainwater (96\%) and less from tap water (19\%) while only $47.5 \%$ of the total population in Mbarara Municipality can afford piped water. The remaining $52.5 \%$ of the population in the municipality use unprotected groundwater water sources like boreholes, springs, wells and rainwater etc to access drinking water [11] [13]. Generally, safe water coverage in Mbarara district was estimated at $64.8 \%$ with hygiene and sanitation remaining very big problems. As such dirty water and water borne diseases have taken a heavy tool 
on the people of Mbarara [11].

The Water borne diseases could be prevented by adopting water safety plans which include locating latrines and other point sources of potential faecal contamination sufficiently far (beyond 30 metres) from groundwater sources used for drinking purposes to ensure that the risk of pathogen survival is very low. Demarcating protection zones clearly and restricting anthropogenic activities (e.g., dumping of toxic waste, the discharge of undesirable effluents and the use of agricultural fertilizers and pesticides) that may affect water quality [14]. Unfortunately most of the people in Mbarara district and Uganda at large don't adhere to some of these water safety plans [15].

Bacterial total coliform and Escherichia coli (E. coli) examination provide indication of the hygienic condition of drinking water and are major tools in the assessment of the health risk borne by pathogen in water. Unfortunately, there is insufficient information on the total coliform and E. coli amounts in the common drinking water sources in Mbarara Municipality, Uganda despite the eminent sources of contamination. Hence the study established the sanitary risk and quantified the total coliform and E. coli load in selected drinking water sources in Mbarara Municipality, Uganda.

\section{Materials and Methods}

\subsection{Location of Study Area}

Mbarara municipality is densely populated with population of 194,973 people [16] and growth rate of $2.9 \%$. The municipality is divided into Nyamitanga, Kamukuzi and Kakoba divisions. There is a great pressure exerted on drinking water sources (boreholes, springs, wells) especially those found in densely populated slum areas of Kakoba and Kiswahili [13]. Hence seven drinking water sources were purposively selected from the three divisions (Nyamitanga, Kamukuzi and Kakoba) of Mbarara municipality which included; 1 spring i.e. Spring (Kise) $\left(0.6004^{\circ} \mathrm{S}, 30.6682^{\circ} \mathrm{E}\right)$ and 1 well i.e. Well (Kise) $\left(0.6030^{\circ} \mathrm{S}, 30.6655^{\circ} \mathrm{E}\right)$ in Kisenyi village (Kakoba), 1 spring i.e. Spring (Kisw) $\left(0.6109^{\circ} \mathrm{S}, 30.6631^{\circ} \mathrm{E}\right)$ in Kiswahili village (Kakoba). Two boreholes in Nyamitanga village at Nyamitanga Secondary School i.e. Borehole (Nyam. S.S) $\left(0.6257^{\circ}\right.$ S, $\left.30.6501^{\circ} \mathrm{E}\right)$ and Shuhaddea Secondary School i.e. Borehole (Shud. S.S) $\left(0.6262^{\circ} \mathrm{S}, 30.6532^{\circ} \mathrm{E}\right)$ (Nyamitanga). One shallow well i.e. S. well (Nyam) $\left(0.6254^{\circ} \mathrm{S}, 30.6607^{\circ} \mathrm{E}\right)$ in Kitebero village (Nyamitanga) and rainwater i.e. Rain (MUST) $\left(0.6164^{\circ} \mathrm{S}, 30.6561^{\circ} \mathrm{E}\right)$ at Mbarara University of Science and Technology (MUST). The map of the study area and the selected water sources is shown in Figure 1. The details of the study area, Mbarara Municipality including the selected water sources are fully described in [17].

\subsection{Sanitary Inspection of the Water Sources}

A cross-sectional sanitary assessment was carried out in each of the selected drinking water sources to identify the risks for contamination with faecal bacterial organisms similar to what [18] did for springs in Katwe and Kisenyi pari- 


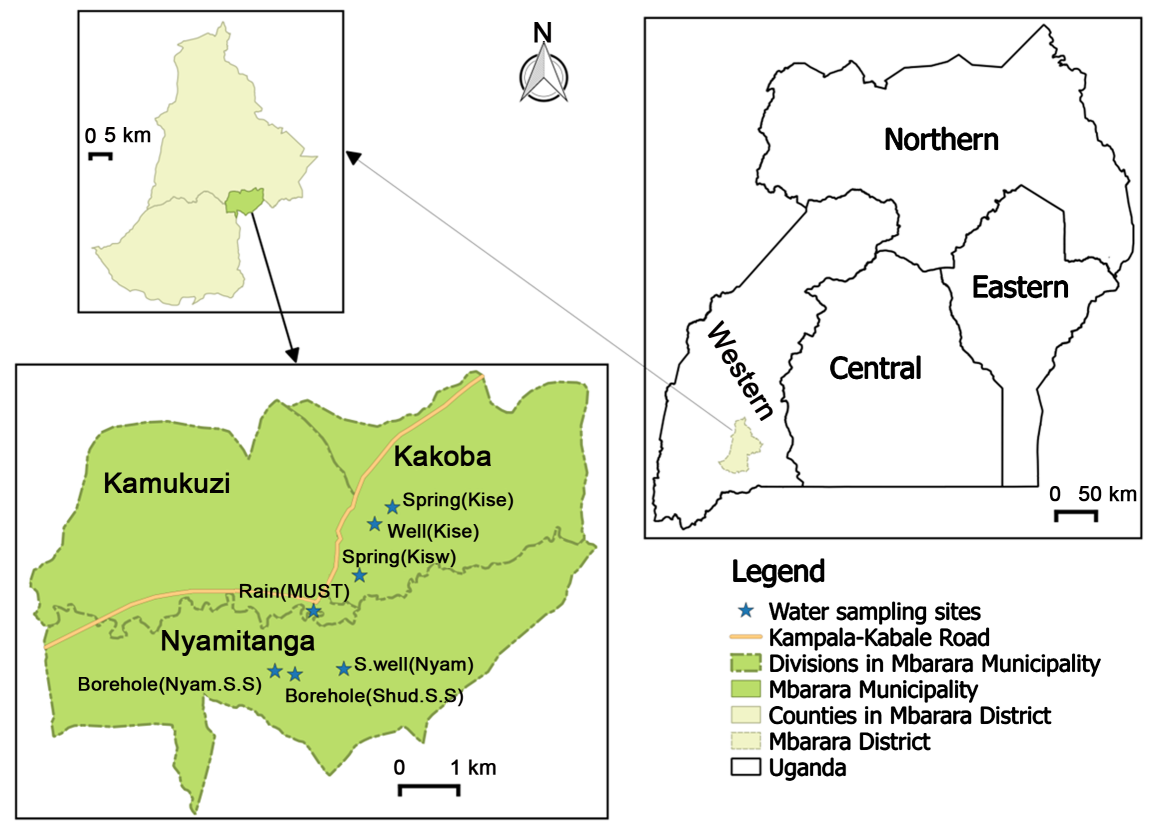

Figure 1. Map of Mbarara municipality showing the location of drinking water sources. Adopted from [17].

shes, Kampala city, Uganda. The assessment adapted the standardised procedure which involved completing a ten-point standardised data form with a set of questions having a yes and no options for designated risks [18] [19]. For each "yes" answer (risk observed), a score of one point was awarded while zero point was given for each "no" answer (no risk observed). A final risk score was obtained by summing all "yes" scores thus giving the overall assessment of the risk profile of each water source. The total sanitary risk score was converted to a percentage. The aggregate risk score was graded as very high ( $81 \%$ to $100 \%)$, high (51\% to $80 \%)$, medium ( $31 \%$ to $50 \%)$, low (1\% to $30 \%$ ) and nil ( $0 \%)$.

\subsection{Collection of Water Samples}

Water samples were collected from the selected water sources from January, 2016 to May, 2016. All water samples were collected and preserved following the Standard methods for Examination of water and wastewater [20] and the [21] guidelines for drinking water sampling. A total of 70 water samples were collected from the seven drinking water sources (2 boreholes, 2 springs, 2 wells (shallow well, deep well) and rainwater) with ten samples from each water source. The ten rainwater samples were collected directly from a rainfall after an hour of downpour in an open space to be used as a control. The water samples were collected in $300 \mathrm{ml}$ sterile glass bottles and immediately placed in an ice box containing ice blocks so as to maintain a low temperature of about $4^{\circ} \mathrm{C}$ so as to prevent multiplication of the microorganisms. The samples were then transported to the microbiology laboratory for bacteriological analysis. The bacteriological parameters analysed included total coliforms and E. coli. The physicochemical parameters of the same drinking water sources in Mbarara Municipality are found in [17]. 


\subsection{Water Sample Preservation}

Water samples that were not immediately analysed for bacteriological parameters (total coliforms, Escherichia coli), were preserved in a refrigerator at temperatures below $4^{\circ} \mathrm{C}$ to slow down the chemical reactions in the water [22] until they were analysed in the microbiology laboratory, Mbarara University of Science and Technology.

\subsection{Determination of Bacteriological Parameters (Total Coliforms and E. coli)}

The Most Probable Number (MPN) method [20] was used to determine the abundance of total coliforms and $E$. coli in the water samples.

\subsubsection{Enumeration of Total Coliforms}

Five tubes containing double strength MacConkey broth $(10 \mathrm{ml})$ were each inoculated with a sub water sample $(10 \mathrm{ml})$ from the same water sample. Using a sterile pipette, five tubes containing single strength MacConkey broth $(5 \mathrm{ml})$ were each inoculated with a sub water sample $(5 \mathrm{ml})$ from the same water sample. To other five tubes containing single strength MacConkey broth $(5 \mathrm{ml})$, a sub water sample $(1 \mathrm{ml})$ was inoculated into each tube using a sterile pipette. The tubes were closed and shook to distribute the sample uniformly throughout the medium and to ensure that the Durham tube inside had no air. The tubes were then incubated at $35^{\circ} \mathrm{C}$ for 24 hours. The above procedure was done to each of the water samples collected. After 24 hours the incubated tubes were examined for gas production and lactose fermentation. The tubes that showed production of gas and acid were isolated, recorded and considered positive for total coliforms. The MPN of total coliform was read off from the Standard MPN table.

\subsubsection{Enumeration of E. coli}

From each of the positive tubes for total coliforms, a sample $(1 \mathrm{ml})$ was removed and inoculated into MacConkey broth single strength $(5 \mathrm{ml})$ and incubated at $44.5^{\circ} \mathrm{C}$ for 48 hours. The tubes were examined for gas production and acid production. The positive tubes were isolated and were taken as positive for faecal coliforms. Using a sterile inoculating loop, cultures in the tubes positive for faecal coliforms were inoculated on MacConkey Agar and sub cultured at $37^{\circ} \mathrm{C}$ for 24 hours. The sub cultures were examined for the growth of $E$. coli colonies. The positive colonies were inoculated using a sterile loop into different tubes containing tryptone water and incubated at $37^{\circ} \mathrm{C}$ for 24 hours. To each tube of tryptone water Kovac's reagent $(0.1 \mathrm{~mL})$ were added and mixed gently. The presence of Indole was indicated by a red colour in the Kovacs reagent, forming a film over the aqueous phase of the medium. Presence of Indole, growth, and gas production showed the presence of $E$. coli which was later confirmed using the IMViC reactions.

The most probable number of $E$. coli in each samples was determined by recording down the tubes positive for $E$. coli in a sample with respect to the dif- 
ferent amounts of the sub samples that were inoculated for total coliforms (10, 5 and $1 \mathrm{ml}$ ) and the MPN of E. coli was read off from the Standard MPN table.

\subsection{Data Analysis}

The descriptive statistics (range, mean, standard deviation, coefficient of variation) of the MPN total coliform and $E$. coli counts of the water samples were tabulated. The total coliform and E. coli counts in the water sources were compared with the WHO drinking water standards. Mean differences of the total coliform and E. coli counts between water sources were compared using oneway ANOVA (F) test. The relationship between bacterial counts with sanitary risk score, proximity of latrines and landfills and physico-chemical parameters [17] were established using Pearson's correlation coefficient (r). The inferential tests were performed at 5\% level of significance. The data presentations and analyses were done by using Microsoft Excel 2007 and SPSS 20.0 statistical packages.

\section{Results and Discussion}

\subsection{Sanitary Risk Assessment of the Drinking Water Sources}

Sanitary inspection is a vital tool in assessing risks of the bacterial contamination of water sources including spring water [18] [19]. It is beneficial in identifying causes of contamination, risk of future contamination and overall assessment of operation and maintenance of water supplies [14] [18] [19]. The sanitary risk assessment of the selected groundwater sources (boreholes, springs, wells) in the study areas for bacterial contamination is shown in Table 1 .

All the six groundwater sources studied faced some risk of contamination with bacterial faecal organisms. The qualitative aggregate risk scores ranged from medium to high. Three of the water sources had a medium risk score (31\% - 50\%) and three had a high risk score $(51 \%-80 \%)$ as shown in Table 1 . There

Table 1. Risk assessment scores of selected groundwater sources in Mbarara Municipality, Uganda.

\begin{tabular}{cccc}
\hline Water source & Risk observed & Percent risk score & Qualitative risk profile \\
\hline Borehole (Nyam. S. S) & $3,5,6,9,10$ & 50 & Medium \\
Borehole (Shud. S. S) & $3,4,5,6,9,10$ & 60 & High \\
Spring (Kisw) & $3,5,6,7,10$ & 50 & Medium \\
Spring (Kise) & $3,5,7,9,10$ & 50 & Medium \\
Well (Kise) & $3,5,6,7,9,10$ & 60 & High \\
S. well (Nyam) & $3,4,5,6,7,9,10$ & 70 & High \\
\hline
\end{tabular}

Nyam. S. S: Nyamitanga Secondary School; Shud. S. S: Shuhaddea Secondary School; Kisw: Kiswahili; Kise: Kisenyi; S. well: Shallow well; Nyam: Nyamitanga. Key to risks observed: 1 = Water source unprotected; $2=$ Masonry protecting water source faulty; $3=$ Backfill area eroded; $4=$ Spilt water floods collection area; $5=$ Perimeter fence absent; 6 = Animals have access within radius $10 \mathrm{~m}$ of water source; 7 = Pit-latrine uphill and/or within $30 \mathrm{~m}$ of water source; $8=$ Surface water collects upstream of water source; $9=$ Diversion ditch above water source absent/non-functional; $10=$ Other pollution sources uphill of water source e.g., solid waste dumps, faeces, stagnant water, and drainage channels. 
was no water source with a very high $(81 \%$ to $100 \%)$ or no $(0 \%)$ risk score. The common risks identified were access by animals within a radius $10 \mathrm{~m}$ of water source, presence of pit latrines within a radius of 30 metres from the water source, eroded backfill area, existence of pollution sources e.g. as solid wastes, lack of protective measures like fencing of the water source, and having diversion ditches. The risk assessment was not done for direct rainfall water which is not a groundwater source and thus it was assumed to have no eminent bacterial contamination source hence used as a control.

Sanitary risk assessment of the drinking water sources showed that shallow well at Nyamitanga and well in Kisenyi both had high bacterial contamination risk while springs at Kiswahili and Kisenyi had medium contamination risk. [15] reported that shallow wells in Budaka District, Uganda were very vulnerable to pollution They further found out that shallow well sanitation was significant to E. coli pollution of the water sources in Budaka District, Uganda. Both springs in Kiswahili and Kisenyi, Mbarara Municipality posed medium risk of bacterial contamination similar to the contamination risk for Kasule, Maama Betty and Bwanika I springs in Katwe and Kisenyi parishes, Kampala city, Uganda reported by [18].

\subsection{Total Coliforms and Escherichia coli in the Selected Drinking Water Sources}

Total coliforms include bacteria which are found in the soil, water and animal or human wastes [23]. The coliform bacterium which is the primary bacterial indicator for faecal pollution in water [24] [25] was present in all the selected drinking water sources. The ranges of the MPN of total coliform and E. coli per 100 $\mathrm{ml}$ in the water samples are shown in Table 2 . There were wide variations in the mean counts of the total coliforms and E. coli $(\mathrm{CV}>10 \%)$ within samples of the water sources (Table 2).

Mean total coliforms and $E$. coli counts significantly $(p<0.05)$ varied among the selected water sources.

The highest mean total coliform and $E$. coli counts were recorded in the shallow well at Nyamitanga i.e. S. well (Nyam.) followed by the well in Kisenyi i.e., Well (Kise). The spring in Kisenyi i.e. Spring (Kise) had the third highest E. coli counts while borehole in Nyamitanga secondary school i.e. Borehole (Nyam. S. S) recorded the third highest mean total coliform counts as detailed in Table 2.

Boreholes in Nyamitanga and Shuhaddea secondary schools, well in Kisenyi and shallow well in Nyamitanga had mean total coliform bacterial count beyond the World Health Organization [17] [26] and Canadian [27] [28] recommended guideline level for drinking water of 10 total coliforms per $100 \mathrm{ml}$. The two studied spring waters in Kiswahili and Kisenyi all recorded total coliforms. [17] reported $90 \%$ detection of the same microbial groups from protected springs in Katwe and Kisenyi parishes, Kampala city, Uganda. Microbial studies of spring water in Natete, Kampala found faecal contamination of the spring water [29], a phenomenon similar to spring (Kise) and spring (Kisw) in the present study. 
Table 2. Bacterial counts of selected drinking water sources and the proximity of the water sources to some anthropogenic activities in Mbarara Municipality.

\begin{tabular}{|c|c|c|c|c|c|c|c|c|c|c|}
\hline \multicolumn{2}{|c|}{$\begin{array}{l}\text { Water source } \\
\quad(\mathrm{n}=10)\end{array}$} & \multirow{2}{*}{$\begin{array}{c}\text { Borehole, } \\
\text { Nyam. S. S } \\
109-177\end{array}$} & \multirow{2}{*}{$\begin{array}{c}\text { Borehole, } \\
\text { Shud. S. S } \\
25-63\end{array}$} & \multirow{2}{*}{$\begin{array}{l}\text { Spring } \\
\text { (Kisw) }\end{array}$} & \multirow{2}{*}{$\begin{array}{l}\begin{array}{c}\text { Spring } \\
\text { (Kise) }\end{array} \\
0-20\end{array}$} & \multirow{2}{*}{$\begin{array}{c}\begin{array}{c}\text { Well } \\
(\text { Kise })\end{array} \\
130-920\end{array}$} & \multirow{2}{*}{$\begin{array}{c}\begin{array}{c}\text { S. well } \\
(\text { Nyam })\end{array} \\
240-1600\end{array}$} & \multirow{2}{*}{$\begin{array}{l}\begin{array}{l}\text { Rain, } \\
\text { MUST }\end{array} \\
0-5\end{array}$} & \multirow[t]{2}{*}{$\begin{array}{l}p \text {-value } \\
\text { (F test) }\end{array}$} & \multirow[t]{2}{*}{$\begin{array}{c}\text { WHO (1993) } \\
\text { standard }\end{array}$} \\
\hline & Range & & & & & & & & & \\
\hline Total & Mean & 145.00 & 44.60 & 4.00 & 9.50 & 320.20 & 807.40 & 1.30 & 0.00 & 10 \\
\hline \multirow[t]{3}{*}{$(\mathrm{CFU} / 100 \mathrm{ml})$} & SD & 23.71 & 11.29 & 4.32 & 6.74 & 239.56 & 579.23 & 1.64 & & \\
\hline & $\% \mathrm{CV}$ & 16.35 & 25.31 & 108.00 & 70.95 & 74.82 & 71.74 & 126.15 & & \\
\hline & Range & $0-0$ & $0-6$ & $0-7$ & $0-12$ & $2-25$ & $11-43$ & $0-0$ & & \\
\hline \multirow{3}{*}{$\begin{array}{c}\text { E. coli } \\
\text { (CFU/100 ml) }\end{array}$} & Mean & 0.00 & 2.40 & 1.20 & 3.40 & 11.60 & 20.90 & 0.00 & 0.00 & 0 \\
\hline & $\mathrm{SD}$ & 0.00 & 2.41 & 2.57 & 4.20 & 6.28 & 10.62 & 0.00 & & \\
\hline & $\% \mathrm{CV}$ & 0.00 & 100.42 & 214.20 & 123.53 & 54.14 & 50.81 & 0.00 & & \\
\hline \multirow[t]{4}{*}{ Proximity $(\mathrm{m})^{*}$} & Animal farms & - & 23 & - & - & 2 & - & & & \\
\hline & Latrine & 37 & 53 & 17 & 4 & 20 & 2 & & & \\
\hline & Landfills & 12 & 33 & 58 & 11 & 12 & 7 & & & \\
\hline & Municipal waste & - & - & 4 & - & 26 & - & & & \\
\hline
\end{tabular}

SD: standard deviation; \% CV: percent of coefficient of variation; Nyam. S. S: Nyamitanga Secondary School; Shud. S. S: Shuhaddea Secondary School; Kisw: Kiswahili; Kise: Kisenyi; Nyam: Nyamitanga; S. well: Shallow well; MUST: Mbarara University of Science and Technology; -: represents no anthropogenic activity; ${ }^{*}[17]$.

However, total coliform in the springs in Kiswahili and Kisenyi and the rainwater in Mbarara University of Science and Technology were below 10 CFU/100 $\mathrm{ml}$. [15] found out that the water quality compliance to Uganda National Bureau of Standards (UNBS) guidelines for biological quality as $97 \%, 73 \%$ and $63 \%$ for boreholes, protected springs and shallow wells respectively signifying that shallow wells are most contaminated followed by springs and boreholes. But the studied boreholes had more total coliform than spring waters contrary to the water quality compliance reported by [15]. However, the total coliform content in all the selected water sources from Mbarara Municipality were within the Directorate of water resource management Uganda (DWRMU) guideline for untreated supplies of water in the rural of $<50 \mathrm{cfu} / 100 \mathrm{ml}$ [3].

Borehole in Shuhaddea Secondary School springs in Kiswahili and Kisenyi, Shallow well in Nyamitanga and well in Kisenyi had E. coli beyond the World Health Organization [26] guideline value of 0 while the borehole in Nyamitanga secondary school and the rainwater at MUST did not have E. coli. According to WHO guidelines, $E$. coli should not be detectable in any water intended for drinking [14] [30] i.e. it should be $0 \mathrm{CFU} / 100 \mathrm{ml}$. [15] also found higher E. coli amounts in shallow wells in Budaka District, Uganda than the WHO water quality guideline ( 0 E. coli $1000 \mathrm{ml})$.

Overall mean E. coli was the highest in Shallow well in Nyamitanga followed by well in Kisenyi (Table 2), spring waters $(2.3 \mathrm{CFU} / 100 \mathrm{ml})$ and boreholes (1.2 $\mathrm{CFU} / 100 \mathrm{ml})$. The trend of $E$. coli in these water sources is in agreement with the compliance of shallow wells, protected springs and boreholes to Uganda Na- 
tional Bureau of Standards (UNBS) water quality guidelines of $63 \%, 73 \%$ and 97\% respectively [15].

The variations of the total coliforms and $E$. coli counts among the selected water sources are related to the bacterial contamination risks posed to the various water sources. Pearson correlation coefficient $(\mathrm{n}=6)$ showed significant $(p$ $<0.05)$ strong positive correlations between the sanitary risk scores for the groundwater sources and the mean total coliform and $E$. coli counts $(r=0.862$, and $r=0.888$, respectively). This significant strong positive correlation proved the reliability of the use of sanitary scores for preliminary risk assessment of contamination of water sources with faecal bacterial organisms. [18] also obtained positive strong correlation of total coliform counts with the sanitary score for springs in Katwe and Kisenyi parishes, Kampala city, Uganda. An earlier study by [31] reported a related correlation in several developing countries.

The proximity of the water sources to human and animal faecal sources as well as landfills [17] also played a significant role in total coliform and E. coli contamination of the water sources (Table 2). Pearson's correlation coefficient $(\mathrm{n}=6)$ showed moderate negative correlation between mean total coliforms and E. coli counts with proximity of latrines $(\mathrm{r}=-0.446$, and $\mathrm{r}=-0.551$, respectively) and proximity of landfills $(r=-0.535$, and $r=-0.502$, respectively) though statistically insignificant $(p>0.05)$. The moderate negative correlation between mean total coliforms and $E$. coli counts with proximity of latrines and landfills showed the effect of the proximity of pit latrines and landfills to bacterial contamination of the water sources. Thus the nearer the pit latrines and landfills are to the water sources, the higher the level of bacterial contamination and vice versa.

The location of a latrine uphill within $10 \mathrm{~m}$ showed the greatest positive association with contamination in Mbale, Uganda [32]. Moreover, the latrines in the present study were located $2 \mathrm{~m}$ and $4 \mathrm{~m}$ to the shallow well in Nyamitanga and spring in Kisenyi respectively hence contributing significantly to the bacterial contamination of the shallow well and spring. According to [15], latrine proximity to shallow wells was significant to $E$. coli pollution of the water sources in Budaka District, Uganda. Furthermore, proximity of some boreholes to solid waste dumpsites and animal droppings being littered around them are also potential contaminants of the quality of groundwater [33] [34]. Hence the location of the well in Kisenyi $2 \mathrm{~m}$ to animal farms and position of S. well (Nyam), Spring (Kise), Well (Kise) and Borehole (Nyam. S. S) at 7, 11, 12 and $12 \mathrm{~m}$ respectively to landfills [17] contributed a lot to the bacterial contamination of the water sources in the present study. Therefore the presence of coliform bacteria in water sources close to the latrines, animal farms and landfills signifies that the source waters are polluted with coliform bacteria from faecal material of humans or other animals originating from the above mentioned sources rather than from soil. Pit latrines are sources of bacteria to groundwater and the presence of coliform bacteria in water is a sign that the source water is polluted with coliform bacteria from faecal material of humans or other animals [1] [35] [36]. [18] also 
attributed the microbial (bacterial) load into springs in Katwe and Kisenyi parishes, Kampala city, Uganda to sub-surface leaching from pit latrines.

Furthermore, sampling of the water in the present study was done between January to May 2016 which coincided with the rain season of Mbarara district and this could have accounted for the high total coliform and E. coli counts in some of the water sources. According to [16], Mbarara records bi-annual rainfall pattern, one of which is in the months of February-May. The high total coliform counts could probably have been as a result of sub-surface infiltration during heavy rainfall. In Uganda, subsurface infiltration has been demonstrated to coincide with heavy rainfall [37] [38]. Different studies have associated rainfall events to high counts of E. coli [29] [39]. According to [3] heavy rainfall causes contamination of water sources. Floods from rainfall transport faecal matter from the ground or sewers and contaminate wells, boreholes and surface waters [40]. [18] also attributed the microbial (bacterial) load into springs in Katwe and Kisenyi parishes, Kampala city, Uganda to direct washing of faecal material. Unfortunately some of the urban population of Mbarara use uncovered pit latrine (13\%) and bush (3\%) as toilet facilities [11] and this could have exacerbated the bacterial contamination during the heavy rainfall periods.

The relatively high mean total coliforms and $E$. coli in well at Kisenyi could also be attributed to the poor sanitation in Kisenyi due to its slum nature [13] and to the high population density. Overcrowding in slums reduces the adequate distance between wells and pit latrines causing contamination of the wells. The findings of a study by [41] in Langas slum, Kenya with $40 \%$ of the pit latrines situated in a distance less than $15 \mathrm{~m}$ from wells showed that fecal matter heavily contaminated the water sources especially the shallow wells. However the well in Kisenyi (a slum area) was situated $20 \mathrm{~m}$ from the latrine but still less than the 30 $m$ distance recommended by world health organization [15] hence the high bacterial contamination levels. In addition, the high human densities in the slum areas are associated with microbial contamination of water as a result of human faeces and animal waste disposal [39] [42].

E. coli presence in springs in Kiswahili and Kisenyi and the borehole in Shuhaddea secondary school agrees with the findings of [43] that showed presence of $E$. coli in springs and boreholes in Mbarara Municipality. However the present study registered an increase in $E$. coli in springs (0 - $12 \mathrm{CFU} / 100 \mathrm{ml})$ and boreholes $(0-6 \mathrm{CFU} / 100 \mathrm{ml})$ compared to the previous findings of [44] which recorded $E$. coli in springs and boreholes ranging between 0 and 3 counts per $100 \mathrm{ml}$ of water.

Rainwater from Mbarara University of Science and Technology which was collected from direct rainfall after an hour of downpour recorded no $E$. coli counts. This could mainly be attributed to improved hygiene in the university environment and hence no $E$. coli ended into surrounding atmosphere of the university with either soil or particulate matter. Additionally, the toilet facilities at the university are improved with no spills of faecal materials into the environment. Furthermore there were also no animal farms in the university com- 
pound. However the minute abundance of total coliforms in the rainwater could have emanated from windblown soil particles into the atmosphere. According to [23] total coliforms include bacteria which are also found in the soil but not only in water, animal or human wastes.

\subsection{Effect of the Physico-Chemical Parameters on the Abundance of $E$. coli in the Selected Potable Water Sources}

The correlation analysis $(\mathrm{n}=70)$ indicated that total coliform and $E$. coli were significantly $(p<0.05)$ positively correlated with $\mathrm{pH}(\mathrm{r}=0.483$, and $\mathrm{r}=0.525$, respectively), and negatively correlated with dissolved oxygen (DO) $(r=-0.267$, and $r=-0.247$, respectively). There was insignificant $(p>0.05)$ correlation of total coliform and E. coli with other physico-chemical parameters (temperature, biological oxygen demand, total hardness, electrical conductivity and total dissolved solids). Early studies have reported E. coli growth and replication to be influenced by physico-chemical parameters like $\mathrm{pH}$ and many others [44].

The significant positive correlation between $E$. coli abundance and $\mathrm{pH}$ is most likely due to the fact that $E$. coli survives well in environments with $\mathrm{pH}$ ranging between 5.5 and 8.5. Within this range increase in $\mathrm{pH}$ causes an increase in growth and replication of $E$. coli hence the positive correlation. [45] reported that $E$. coli counts increase with increase in $\mathrm{pH}$ and decrease when $\mathrm{pH}$ is beyond 9. This supports the positive correlation since the $\mathrm{pH}$ of the water sources was generally below 9. [46] reported that decrease in $\mathrm{pH}$ beyond 5 causes a decrease in the viability of the $E$. coli populations. On the other hand, the significant negative correlation between $E$. coli and dissolved oxygen could be attributed to $E$. coli being a facultative anaerobe which enables it to survive and replicate even in oxygen depleted environments hence the increase in abundance of $E$. coli as oxygen decreases [47]. This concurs with [48] who found out that some strains of $E$. coli prefer surviving better under anaerobic conditions than aerobic conditions.

\section{Conclusions}

The sanitary risk assessment score is a reliable tool for predicting the possible levels of bacterial contamination of drinking water sources in Mbarara municipality.

The results indicated that there is a strong linkage between microbiological (total coliforms and E. coli) water quality and water source sanitation, as well as the proximity of latrines, animal farms and landfills around the water sources.

All the studied groundwater sources (boreholes, springs and wells) in Mbarara Municipality were not compliant to either both or one of the WHO total coliform and $E$. coli criteria for drinking water hence they are unsuitable for drinking without treatment e.g. boiling etc.

Only rainwater collected from Mbarara University of Science and Technology met the WHO total coliform and $E$. coli criteria for drinking water thus is suitable for drinking without any treatment. 
Mbarara municipal council should therefore ensure that pit latrines and animal farms are not located within WHO recommended minimum proximity of $30 \mathrm{~m}$ to the groundwater sources (boreholes, springs and wells).

Mbarara municipal council should also ensure effective and regular operation and maintenance of the drinking water sources through the adoption and promotion of appropriate Water Safety Plans.

\section{Acknowledgements}

The authors wish to thank the entire Department of Biology of Mbarara University of Science and Technology for the support and guidance they offered during the entire research and preparation of the paper.

\section{References}

[1] Rather, M.A., Sharma, H.K., Kandoi, M. and Rao, R.J. (2013) Quality Assessment of Some Local Packaged Water Brands in Gwalior City (M.P), India. International Journal of Environmental Biology, 3, 180-185.

[2] John, R. (1993) Running out of Water. People \& the Planet, 2, 2-3.

[3] Nafi'u, A. and Anandapandian, K.T.K. (2016) The Occurrence of Waterborne Diseases in Drinking Water in Nakaloke Sub-County, Mbale District, Uganda. International Journal of Science and Research (IJSR), 5, 1416-1421.

[4] Dick, S.M., Handzel, T. and Venczel, L. (2003) Chlorination and Safe Storage of Household Drinking Water in Developing Countries to Reduce Waterborne Disease. Journal of Water Science and Technology, 47, 221-228.

[5] Mohammed, S., Demena, T.G.M., Workie, A. and Tadesse, E. (2003) Definition of Waterborne Diseases. Waterborne Diseases for the Ethiopian Health Centre Team. Ethiopian Public Health Initiative, Haramaya University, 13.

[6] Nygard, K. (2008) Water and Infection Epidemiological Studies of Epidemic and Endemic Waterborne Diseases. Masters Dissertation, Norwegian Institute of Public Health, 11-20.

[7] Bwire, G., Malimbo, M., Maskery, B., Kim, Y.E., Mogasale, V. and Levin, A. (2013) The Burden of Cholera in Uganda. PLoS Neglected Tropical Diseases, 7, e2545. https://doi.org/10.1371/journal.pntd.0002545

[8] Water and Sanitation Program (2012) Uganda Economic Impacts of Poor Sanitation in Africa. https://www.wsp.org/sites/wsp.org/files/publications/WSP-ESI-Uganda.pdf

[9] World Health Organization and United Nation International Children Emergency Funds (2012) Joint Monitoring Programme. World Health Organisation Press, 1.

[10] World Health Organization and United Nations Childrens Fund (2014) Progress on Drinking Water and Sanitation 2014 Update. World Health Organisation.

[11] Mbarara District Planning Unit (2009) Higher Local Government Statistical Abstract Mbarara District. Mbarara, Uganda.

[12] UN-Water World Water Assessment Programme (2006) National Water Development Report. Prepared for 2nd UN-World Water Development Report Water a Shared Responsibility. Uganda.

[13] Mbarara Municipality (2009) Mbarara Municipality Council Development Plan 2009-2012. Mbarara Municipality Press, Mbarara.

[14] WHO (1997) Guidelines for Drinking Water Quality, Vol. 3: Surveillance and Con- 
trol of Community Water Supplies. 2nd Edition, World Health Organisation, Geneva.

[15] Nabucha, A. and Rugumayo, A.I. (2015) Water Quality Assessment in a Rural Setting: A Case Study of Budaka District. UNESCO International Scientific Symposium, Kyoto-Otsu, 15-18 July 2015.

http://www.unescokyotosympo2015.org/abstracts/Rugumayo\%20-\%20Water\%20Q uality\%20Assessment\%20in\%20a\%20Rural\%20Setting.pdf

[16] Uganda Bureau of Statistics (2014) Statistical Abstract. Kampala. Republic of Uganda, Kampala.

[17] Lukubye, B. and Andama, M. (2017) Physico-Chemical Quality of Selected Drinking Water Sources in Mbarara Municipality, Uganda. Journal of Water Resource and Protection, 9, 707-722. https://doi.org/10.4236/jwarp.2017.97047

[18] Haruna, R., Ejobi, F. and Kabagambe, E.K. (2005) The Quality of Water from Protected Springs in Katwe and Kisenyi Parishes, Kampala City, Uganda. African Health Sciences, 5, 14-20.

[19] Howard, A.G. (2002) Water Supply Surveillance: A Reference Manual. WEDC, Loughborough University.

[20] American Public Health Association (2012) Standard Methods for Examination of Water and Waste Water. 22nd Edition, American Public Health Association Press, Washington DC.

[21] World Health Organisation (2004) World Health Organisation Guidelines for Drinking Water Quality. World Health Organisation Press, Geneva.

[22] Water Watch Australia Steering Committee (2002) Water Watch Australia National Technical Manual. Environment Australia.

[23] Karikari, A. and Ondi, D. (2004) An Assessment of Water Quality of Angaw River in South-Eastern Coastal Plains of Ghana. CSIR-Water Research Institute, 95, 2336.

[24] Parihar, S.S., Kumar, A., Kumar, A., Gupta, R.N., Pathak, M., Shrivastav, A. and Pandey, A.C. (2012) Physico-Chemical and Microbiological Analysis of Underground Water in and around Gwalior City, MP, India. Research Journal of Recent Science, 1, 62-65.

[25] Mohan, D., Gaur, A. and Chodhary, D. (2007) Study of Limnology and Microbiology of NayaTalab, Jodhpur, Rajasthan. Proceedings of National Symposium on Limnology, 64-68.

[26] World Health Organisation (1993) Guidelines for Drinking Water Quality-Recommendations. 2nd Edition, Vol. 1, World Health Organisation, Geneva.

[27] Anon (2002) Assessment Studies of Water and Waste Water Systems Associated Water Management Practices at Selected First Nation Communities.

[28] Yasin, M., Ketema, T. and Bacha, K. (2015) Physico-Chemical and Bacteriological Quality of Drinking Water of Different Sources, Jimma Zone, Southwest Ethiopia. BMC Research Notes, 8, 541. https://doi.org/10.1186/s13104-015-1376-5

[29] Nsubuga, F.B., Kansiime, F. and Okot, O.J. (2004) Pollution of Protected Springs in relation to High and Low Density Settlements in Kampala, Uganda. Physics and Chemistry of the Earth, 29, 1153-1159.

[30] Cheesbrough, M. (2006) District Laboratory Practice in Tropical Countries. 2nd Edition, Cambridge University Press, New York. https://doi.org/10.1017/CBO9780511543470

[31] Lloyd, B. and Bartman, J. (1991) Surveillance Solutions to Microbiological Problems in Water Quality Control in Developing Countries. Water, Science and Technology, 
24, 61-75.

[32] Guy, H., Nalubega, M., Barrett, M., Pedley, S., Kulabako, R., Haruna, R., Johal, K. and Taylor, I. (2002) Impact of On-Site Sanitation on Groundwater Supplies in Kampala and Iganga, Uganda in ARGOSS Assessing Risk to Ground Water from On-Site Sanitation: Scientific Review and Case Studies. British Geological Survey Commissioned Report CR/02/079N, British Geological 1-16.

[33] Bello, O.O., Osho, A., Bankole, S.A. and Bello, T.K. (2013) Bacteriological and Physicochemical Analyses of Borehole and Well Water Sources in Ijebu-Ode, Southwestern Nigeria. International Journal of Pharmacy and Biological Sciences, 8 , 18-25.

[34] Palamuleni, L. and Akoth, M. (2015) Physico-Chemical and Microbial Analysis of Selected Borehole Water in Mahikeng, South Africa. International Journal of Environmental Research and Public Health, 12, 8619-8630.

https://doi.org/10.3390/ijerph120808619

[35] Bloodless, D., Zvikomborero, H., David, L. and Edward, G. (2006) Assessment of the Impacts of Pit Latrines on Groundwater Quality in Rural Areas: A Case Study from Marondera District, Zimbabwe. Physics and Chemistry of the Earth, 31, 779788.

[36] Tiwari, S. (2015) Water Quality Parameters-A Review. International Journal of Engineering Science Invention Research \& Development, 1, 319-324.

[37] Taylor, R.G. and Howard, A.G. (1995) Groundwater Quality in Rural Uganda: Hydrochemical Considerations for the Development of Aquifers within the Basement Complex of Africa. In: Mccall, J.H., Ed., Groundwater Quality.

[38] Barrett, M.H., Nalubega, M., Howard, A.G., Taylor, R.G. and Pedley, S. (1999) The Impact of On-Site Sanitation on Urban Groundwater Quality in Uganda. In: Fendecova and Fendek, Eds., Hydrogeology and Land Use Management.

[39] Howard, G., Pedley, S., Barett, M., Nalubega, M. and Johal, K. (2003) Risk Factors Contributing to Microbiological Contamination of Shallow Groundwater in Kampala, Uganda. Water Research, 37, 3421-3429.

[40] Curriero, F., Patz, J., Rose, J.B. and Lele, S. (2001) The Association between Extreme Precipitation and Waterborne Disease Outbreaks in the United States, 1948-1994. American Journal of Public Health, 12-29.

[41] Kimani-Murage, E.W. and Ngindu, A.M. (2007) Quality of Water the Slum Dwellers Use: The Case of a Kenyan Slum. Journal of Urban Health, 84, 829-838. https://doi.org/10.1007/s11524-007-9199-x

[42] Kulabako, N.R., Nalubega, M. and Thunvik, R. (2007) Study of the Impact of Land use and Hydrogeological Settings on the Shallow Groundwater Quality in a PeriUrban area of Kampala, Uganda. Science of the Total Environment, 381, 180-199.

[43] Musinguzi, D. (2003) The Status of Water Sources of Mbarara Municipality. Bachelor of Science with Education, Dissertaion, Mbarara University of Science and Technology, Mbarara, 19-20.

[44] Van Elsas, J.D., Semenov, A.V., Costa, R. and Trevors, J.T. (2011) Survival of Escherichia coli in the Environment: Fundamental and Public Health Aspects. ISME Journal, 5, 173-183. https://doi.org/10.1038/ismej.2010.80

[45] Karak, T. and Bhattacharyya, P. (2011) Human Urine as a Source of Alternative Natural Fertilizer in Agriculture: A Flight of Fancy or an Achievable Reality. Resources, Conservation and Recycling, 55, 400-408.

[46] Buchanan, R.L. and Edelson, S.G. (1999) Effect of pH-Dependent, Stationary Phase Acid Resistance on the Thermal Tolerance of Escherichia coli O157:H7. Food Mi- 
crobiology, 16, 447-458. https://doi.org/10.1006/fmic.1998.0260

[47] Levinson, W. (2008) Medical Microbiology and Immunology. 10th Edition, McGraw-Hill Companies, Incorporation, New York.

[48] Audrey, C.K., Kristin, D., Breidt, F. and Hassan, H. (2008) Effects of pH, Dissolved Oxygen, and Ionic Strength on the Survival of Escherichia coli O157:H7 in Organic Acid Solutions. Journal of Food Protection, 71, 2404-2409.

Submit or recommend next manuscript to SCIRP and we will provide best service for you:

Accepting pre-submission inquiries through Email, Facebook, LinkedIn, Twitter, etc. A wide selection of journals (inclusive of 9 subjects, more than 200 journals) Providing 24-hour high-quality service User-friendly online submission system Fair and swift peer-review system Efficient typesetting and proofreading procedure Display of the result of downloads and visits, as well as the number of cited articles Maximum dissemination of your research work

Submit your manuscript at: http://papersubmission.scirp.org/ Or contact jwarp@scirp.org 